\title{
Assessment of Heavy Metal Contamination in Soils around Cassava Processing Mills in Sub- Urban Areas of Delta State, Southern Nigeria
}

\author{
${ }^{1 *}$ C.M.A. Iwegbue, ${ }^{2}$ F.I. Bassey, ${ }^{1}$ G.O. Tesi, ${ }^{1}$ G.E Nwajei and ${ }^{3}$ A.I. Tsafe \\ 1Department of Chemistry, Delta State University, P.M.B. 1, Abraka, Nigeria \\ ${ }^{2}$ Department of Chemistry, University of Calabar, Calabar, Cross-Rivers State, Nigeria \\ 3Department of Chemistry, Usmanu DanFodiyo University, Sokoto, Nigeria.
}

[Correspondence author: Email: maxipriestley@yahoo.com; jindumax@gmail.com; 䍖:+2348033864109]

\begin{abstract}
The concentrations, contamination/pollution index, anthropogenic input and enrichment factors for metals in soil in the vicinity of cassava processing mills in sub-urban areas of Delta State of Nigeria were examined. The concentrations of metals in all sites and depths ranged from 0.1 to $383.2 \mathrm{mg} \mathrm{kg}^{-1}$ for Mn, 4.0 to $11.3 \mathrm{mg} \mathrm{kg}^{-1}$ for Ni, 1746.4 to $2839.6 \mathrm{mg} \mathrm{kg}^{-1}$ for $\mathrm{Fe}, 0.01$ to $3.70 \mathrm{mg} \mathrm{kg}^{-1}$ for $\mathrm{Cr}, 3.7$ to $29.5 \mathrm{mg} \mathrm{kg}^{-1}$ for $\mathrm{Cu}, 21.9$ to $97.3 \mathrm{mg} \mathrm{kg}^{-1}$ for $\mathrm{Zn}, 0.01$ to $1.60 \mathrm{mg} \mathrm{kg}^{-1}$ for $\mathrm{Cd}$ and $<0.01$ to $<0.01 \mathrm{mg} \mathrm{kg}^{-1}$ for $\mathrm{Pb}$. The concentrations of metals at these sites were below the Department of Petroleum Resources target values for metals in soils except for $\mathrm{Cd}$ in some sites. A significant fraction of these metals aroses from anthropogenic sources. The percent anthropogenic fraction of metals in the soil follow the order $\mathrm{Cd}>\mathrm{Zn}>\mathrm{Ni}>\mathrm{Cu}>\mathrm{Fe}>\mathrm{Cr}>\mathrm{Pb}$.

Keywords: Anthropogenic input, cassava, heavy metals, pollution index
\end{abstract}

\section{INTRODUCTION}

Manihot esculentum is a major farm produce in southern Nigeria. It is usually processed into a variety of forms before getting to the consumers. During processing, effluents and other solid wastes are discharged into the environment without any form of treatment. Apart from the fact that cassava effluents contain high cyanide content which has adverse effect on the soil $\mathrm{pH}$, the cassava effluents and other wastes may contain metal ions and other pollutants. The impact of contamination of the environment should be of significant scientific interest in order to minimise the threat to soil fauna, surface and ground water.

Heavy metal contents of soil are of major significance because of their non-degradable nature and ability to accumulate for long period of time (Gallego et al., 2002; Wu and Zhang, 2010). Overload of metal ions in soil environment clearly poses a significant risk to the quality of soils, plants, natural waters and human health (Adraino, 2001). The presence of heavy metasl in soil could be a double edged sword ranging from the role in normal growth of plants and living organisms to toxicity associated with presence of certain metals ( $\mathrm{Pb}, \mathrm{Cd}$ and $\mathrm{Hg}$ etc). The bioavailability of metal ions in soils is influenced by the $\mathrm{pH}$, temperature, redox potential, cation exchange capacity, organic matter, competition with other metal ions, composition and quality of soil (Moon et al., 2000; Mapanda et al., 2005; Skorda and Kelepertsis, 2005; Machender et al., 2010). Studies on heavy metals contamination of soil environments in Nigeria are numerous (Bamgbose et al., 2000;
Onianwa and Fakayode, 2000; Onianwa 2001; Ana and Sridhar, 2004; Umoren and Onianwa, 2005; Iwegbue et al., 2006 a, b; Iwegbue, 2007; Nwajei et al., 2007; Inuwa et al., 2007; Oviasogie and Ofomaja, 2007; Nwajei and Iwegbue, 2007; Osakwe and Egherevba, 2008) with attention paid to industrial sites and contaminated sites in urban centre. Relatively few studies have reported on the impact of cottage industries such as cassava processing in sub-urban and rural soils. Oviasogie and Ofomaja (2007) reported the effect of the discharge of cassava mill effluent on soil at three different processing locations in Benin. The concentrations of available metals ranged from 0.43-2.15, 0.46-1.96, 1.89-11.67, 0.36-1.96 $\mathrm{mg} \mathrm{kg}^{-1}$ for $\mathrm{Mn}, \mathrm{Zn}, \mathrm{Fe}$, and $\mathrm{Pb}$ respectively. In view of the fact that limited data are currently available on the heavy metal status of soils in the vicinity of cassava processing mills this study was undertaken to provide a detailed accounts of the distribution, contamination/pollution and anthropogenic input of heavy metals from cassava processing industries in Delta state, Nigeria.

\section{MATERIALS AND METHODS}

\section{Description of study area}

The study area covered three semi-urban towns of Abraka and Eku located in Ethiope East Local Governmant Area and Obiaruku located in Ukwuani Local Government Area of Delta State. Abraka, a university town lies approximately on longitude $6.03^{\circ}$ to $6.13^{\circ} \mathrm{E}$ and latitude $5.76^{\circ}$ to $5.82^{\circ} \mathrm{N}$ while Eku lies on longitude $5.97^{\circ}$ to $6.01^{\circ} \mathrm{E}$ and latitude $5.72^{\circ}$ to $5.76^{\circ} \mathrm{E}$. Obiaruku is the administrative headquarters of Ukwuani Local Government Area and lies within 
the coordinates of longitude $6.13^{\circ}$ to $6.16^{\circ} \mathrm{E}$ and latitude $5.82^{\circ}$ to $5.85^{\circ} \mathrm{N}$.

\section{Sampling and Analysis}

Soil samples were collected from ten cassava processing mills in Abraka, Eku and Obiaruku in Delta State of Nigeria. A quadrant of $15 \mathrm{~m} \times 15 \mathrm{~m}$ was constructed around the cassava processing mill. The quadrant was further divided into small cells of 5 $\times 5 \mathrm{~m}$ with each cell representing sampling site. At least 2-3 samples were collected randomly at depths of $0-15 \mathrm{~cm}$ and $15-30 \mathrm{~cm}$ using soil auger. Samples collected within a given cell at the same horizon were mixed together. The soil samples were air dried, sieved to pass through $2 \mathrm{~mm}$ mesh and stored at 4 ${ }^{\circ} \mathrm{C}$ in the refrigerator prior to chemical analysis.

The $\mathrm{pH}$ of the soil was measured in a 1:2.5 (m/ $/ \mathrm{v})$ soil to water suspension (8 $\mathrm{g}$ of soil for $20 \mathrm{~mL}$ of distilled water) prepared and left standing overnight (Reeuwijk, 1995; Abollino et al., 2002). Total organic carbon was determined by wet dichromate oxidation method of Walkley and Black as described by Radojevic and Bashkin (1999). One gramme (1.0 g) of the soil sample was digested with $15 \mathrm{~mL}$ of aquaregia $\left(\mathrm{HNO}_{3}: \mathrm{HCl}, 3: 1\right.$ ratio) and was allowed to stand overnight, in the next day the sample was digested at $125{ }^{\circ} \mathrm{C}$ for $2 \mathrm{~h}$. The digest was allowed to cool to room temperature and filtered through Whatman No 1 filter and diluted to $25 \mathrm{~mL}$ with $0.25 \mathrm{~mol} / \mathrm{L} \mathrm{HNO}_{3}$. The samples were subsequently analysed for $\mathrm{Cd}, \mathrm{Pb}, \mathrm{Zn}$, $\mathrm{Ni}, \mathrm{Cu}, \mathrm{Cr}, \mathrm{Fe}$ and $\mathrm{Mn}$ using flame atomic adsorption spectrophotometry (GBC scientific equipment SENS $\mathrm{AA}$, Australia). Matrix matching, standard addition and background correction were used to overcome interference. After every determination, blanks and certified reference materials were also run to determine the precision and instrumental uncertainty. The percent recoveries of metals from the certified reference material were 93.2\%, 94.2\%, 95\%, 89\%, $85 \%, 96 \%, 97 \%$ and $94.3 \%$ for $\mathrm{Cd}, \mathrm{Pb}, \mathrm{Zn}, \mathrm{Ni}, \mathrm{Cu}$, $\mathrm{Cr}$, Fe and $\mathrm{Mn}$ respectively.

Student's $t$ at $95 \%$ confidence level was used to compare variance in metal concentrations among the samples.

Quantification of Anthropogenic metal: Considering the metal content of the control (background sample) as representing lithogenic metal, the proportion of anthropogenic metal was determined for each metal by means of the equation described by Asaah et al. (2005).
Anthropogenic metal $=\frac{X-X_{C}}{X}$

Where $X=$ metal content representing the lithogenic metal

$X_{c}=$ average concentration of metal in the soil

\section{Contamination/pollution index:}

The contamination/pollution index was derived by employing the contamination/pollution index as defined by Lacutusu (2000).

$$
\mathrm{C} / \mathrm{PI}=\frac{\text { Concentration of metal in soil }}{\text { Target value from refeerence table }}
$$

A distinction between soil contamination and pollution range was established by means of the contamination/pollution index C/PI (Table 1). This represents a metal content effectively measured in soil by chemical analysis and the reference value of contamination obtained using the standard table formulated by the Department of Petroleum Resources of Nigeria (DPR, 2002) for maximum allowed concentrations of heavy metals in soil (Table 2). $C / P$ index values greater than unity (1) defines the pollution range and when lowers than unity the contamination range. The standard employed for interpreting soil heavy metals contamination/pollution index varies from country to country based on the chosen factors (Lacatusu, 2000).

Table 1: Significance of intervals of contamination/ pollution index (C/P)

\begin{tabular}{ll}
\hline C/PI & Significance \\
\hline$<0.1$ & Very slight contamination \\
$0.10-0.25$ & Slight contamination \\
$0.26-0.5$ & Moderate contamination \\
$0.51-0.75$ & Severe contamination \\
$0.76-1.00$ & Very severe contamination \\
$1.1-2.0$ & Slight pollution \\
$2.1-4.0$ & Moderate pollution \\
$4.1-8.0$ & severe pollution \\
$8.1-16.0$ & Very severe pollution \\
$>16.0$ & Excessive pollution \\
\hline
\end{tabular}

Adapted from Lactusu (2000)

Table 2: Target values for heavy metals ( $\left.\mathrm{mg} \mathrm{kg}^{-1}\right)$

\begin{tabular}{ccc}
\hline Metals & Target value & Intervention value \\
\hline $\mathrm{Cd}$ & 0.8 & 17 \\
$\mathrm{Cr}$ & 100 & 380 \\
$\mathrm{Cu}$ & 36 & 190 \\
$\mathrm{~Pb}$ & 85 & 530 \\
$\mathrm{Ni}$ & 35 & 210 \\
$\mathrm{Zn}$ & 140 & 720 \\
$\mathrm{Mn}$ & $850^{\star}$ & - \\
$\mathrm{Fe}$ & $4.7^{\star *}$ & - \\
\hline${ }^{*}$ Derived from crustal abundance value & ${ }^{* \star}$ value in $\%$.
\end{tabular}

Adapted from DPR( 2002) 
No guideline value was specified for iron and manganese in soils. Hence, selected crustal abundance values of iron and manganese were used for computation of $\mathrm{C} / \mathrm{PI}$.

\section{Quantification of Enrichment factor}

Heavy metals enrichment factor was derived based on equation described by Asaah et al. (2005) and Iwegbue, (2007)

Enrichment Factor $(E F)=\frac{\text { Mean concentration of heavy metalin soil }}{\text { Background concentration }}$

Enrichment factor is a convenient measure of geochemical trend and is used for making comparisons between an area and overtime.

\section{RESULTS AND DISCUSSION}

Table 3 presents the results of some chemical characteristics of soil in the vicinity of cassava processing sites. The $\mathrm{pH}$ of the soil ranged between 4.0 and 6.5 indicating that the soils were generally acidic in nature. The acidity of the soils may be associated with hydrogen cyanide content of the cassava effluent. However, similar pH values have been reported for Niger Delta soils (Iwegbue et al., $2006 \mathrm{a}, \mathrm{b}$; Oviasogie and Ofomaja, 2007) and some soils in other regions of Nigeria (Noma et al., 2008). Total organic carbon contents of the soils ranged from $0.8-2.8 \%$. The highest per cent organic carbon was observed at site $X$ with a pH value of 4.9. The per cent organic carbon decreased with depths in all the sites. The cation exchange capacity of the soils showed significant variation with respect to sites and depths. The higher values of cation exchange capacity were observed in sites IX and X as compared to any other sites. Similar values of CEC have been reported in soil that received cassava effluents in Benin City, Nigeria (Oviasogie and Ofomaja, 2007).

Table 4 presents the results for total heavy metal concentrations in soils of cassava processing mills. The results indicate significant variations with respect to sites and depths at $95 \%$ probability levels. The top soils generally have higher metal concentrations than the sub soils. At all sites and depths, higher concentrations of metals were observed as compared with concentrations found at the control site except for chromium and lead. This indicates that chromium and lead concentrations in these sites were purely lithogenic. However, site $\mathrm{V}$ has chromium levels higher than that of the control site. The levels of metals found in these sites were below the target and intervention values of metals in soils in Nigeria except for cadmium (DPR, 2002). The concentrations of metals in the examined sites and depths were in the order; $\mathrm{Fe}>\mathrm{Mn}>\mathrm{Zn}>\mathrm{Cu}>\mathrm{Ni}>\mathrm{Cr}>\mathrm{Cd}>\mathrm{Pb}$. The concentration of $\mathrm{Pb}$ was very low in all sites and depths, indicating that $\mathrm{Pb}$ does not constitute contamination hazards at these sites.

Table 3: Some chemical properties of soils in the vicinity of cassava processing mill* in Delta state Nigeria.

\begin{tabular}{ccccc}
\hline Site & Depth $(\mathbf{c m})$ & pH & $\begin{array}{c}\text { TOC } \\
\text { (\%) }\end{array}$ & CEC \\
\hline I & $0-15$ & 4.0 & 1.2 & 25.32 \\
& $15-30$ & 4.1 & 0.9 & 24.41 \\
II & $0-15$ & 4.3 & 1.8 & 45.34 \\
& $15-30$ & 4.0 & 1.3 & 42.25 \\
III & $0-15$ & 4.5 & 1.7 & 24.51 \\
& $15-30$ & 4.3 & 1.2 & 21.41 \\
IV & $0-15$ & 5.2 & 1.7 & 33.45 \\
& $15-30$ & 5.6 & 0.8 & 30.25 \\
V & $0-15$ & 4.8 & 1.5 & 36.78 \\
& $15-30$ & 4.7 & 1.7 & 34.87 \\
VI & $0-15$ & 5.6 & 1.8 & 39.42 \\
& $15-30$ & 4.3 & 1.5 & 33.42 \\
VII & $0-15$ & 6.1 & 2.3 & 58.41 \\
& $15-30$ & 6.3 & 1.8 & 54.28 \\
VIII & $0-15$ & 6.5 & 2.5 & 62.21 \\
& $15-30$ & 6.2 & 1.4 & 59.38 \\
IX & $0-15$ & 5.3 & 2.3 & 80.70 \\
& $15-30$ & 5.2 & 2.0 & 73.41 \\
X & $0-15$ & 4.9 & 2.8 & 80.30 \\
& $15-30$ & 5.0 & 1.9 & 78.31 \\
\hline VI & & 5.3
\end{tabular}

${ }^{*}$ Mean of triplicate analysis. The relative standard deviation for the replicates are $<15 \%$ TOC $=$ Total organic carbon

Iron

The concentrations of iron ranged from 1746.4 to $2839.4 \mathrm{mg} \mathrm{kg}^{-1}$ in all sites and depths (Table 4). The levels of iron found in these sites were lower than values reported in soils in the vicinity of automobile spare parts market (Nwajei and Iwegbue, 2007) and oil field in Nigeria (Iwegbue et al., 2006a). However, Oviasogie and Ofomoja (2007) reported 1.87-117.67 $\mathrm{mg} \mathrm{kg}^{-1}$ as available iron in soils that have received cassava effluents in Benin City, Nigeria. Similarly, Aina and Sridhar (2004), Oviasogie and Omoruyi (2007) and Iwegbue et al. (2009a) observed lower levels of iron in soils around foam manufacturing, 
fertilizer industry and metallic scrap sites respectively as compared to the levels of iron found in these sites. However, in spite of the fact that concentrations of iron found in these sites fitted into common range found in unpolluted soils (Alloway, 2005), significant amounts of iron arises from anthropogenic input. Anthropogenic iron ranged from $14.7 \%$ to $47.5 \%$. This indicates that greater fractions of the iron in these soils are of lithogenic origin (Table 5). The enrichment coefficient for iron ranged between 1.21.9 (Table 6). These values are lower than enrichment coefficient found in soils in the vicinity of automobile parts market in Benin City (Iwegbue and Nwajei, 2007).

\section{Manganese}

The concentrations of manganese ranged between 0.1 and $383.2 \mathrm{mg} \mathrm{kg}^{-1}$ in all sites and depths (Table 4). The maximum value for manganese was observed at topsoil of site $X$. the major source of manganese is considered natural (lithogenic) but in this study, the computed anthropogenic fractions of manganese in these soils ranged from $0-90.2 \%$ (Table 5). The concentrations of manganese in sites IV and $\mathrm{VI}$ are purely lithogenic. However, $\mathrm{Mn}$ and $\mathrm{Ni}$ are fuel additives especially in burning fuel (diesel) that are used in operating these mills (Sheppard et al., 2000; El-Hassan et al., 2006). The concentrations of manganese found in these sites are similar to levels of manganese in soils that have received significant impact of crude oil in Nigeria (Iwegbue et al., 2009b).

\section{Nickel}

The concentrations of nickel in these sites ranged between 4.1 and $11.3 \mathrm{mg} \mathrm{kg}^{-1}$ for all sites and depths (Table 4). The higher nickel concentrations were observed in the top soils of sites IX and V. The levels of nickel observed in the present study were higher than levels observed in some industrial sites in Nigeria (Aina and Sridhar, 2004; Gunshik and Mohammed, 2007; Oviasogie and Omuruyi, 2007;). Higher values of nickel have been reported for soils around industrial areas in India (Machender et al., 2010). However, the levels of nickel observed in the present study were lower than levels found in urban soils in Nigeria (Umoren and Onianwa, 2005), soil profile of automobile mechanic waste dumps (Iwegbue et al., 2006), crude oil contaminated soil (Iwegbue et al., 2009), soils in automobile workshops (Oguntimehin and Ipimoroti, 2008) and those found in contaminated sites elsewhere in the world (Kashem et al., 2007; Abollino et al., 2002). As mentioned earlier, anthropogenic source of nickel in this zone are usually cassava wastes and diesel used in operating the mill. The fraction of nickel due to anthropogenic origin ranged from $36.8 \%$ to $77.6 \%$ (Table 5). The lithogenic nickel was less than $50 \%$ in all sites except for sub soils for sites I, V and VIII. With respect to contamination index, the soils of cassava processing mills could be ranked as slightly contaminated to moderately contaminated with nickel.

\section{Chromium}

The levels of chromium observed in these sites range from 0.01 to $3.70 \mathrm{mg} \mathrm{kg}^{-1}$. All sites have chromium concentration lower than that of background (control) except for site $V$. this implies the presence of chromium in these sites is due to lithogenic origin except at site $\mathrm{V}$ that has $72.2 \%$ anthropogenic chromium. Similar low levels of chromium have been observed in surface soils under waste dumps in Onitsha, Nigeria (Nwajei et al., 2007) and soils around foam manufacturing industry (Oviasogie and Omoruyi, 2007). The levels of chromium found in this study was relatively low compared to chromium levels reported for soil profiles of automobile workshops (Oguntimehin and Ipimoroti, 2008), urban soils (Umoren and Onianwa, 2005), soil profile automobile mechanic waste dumps (Iwegbue et al., 2006b), crude oil contaminated soils (Iwegbue et al., 2009b) and soils of municipal waste dumps (Osakwe and Egharevba, 2008).

\section{Copper}

The concentration of copper in the soil ranged between 3.7 and $29.5 \mathrm{mg} \mathrm{kg}^{-1}$. The highest mean levels of copper were observed in the topsoil of sites II and $X$. The levels of copper found in all sites in this study were below the selected average $(13-24 \mathrm{mg} \mathrm{kg}$ $\left.{ }^{1}\right)$ reported by Alloway (2005) for soil except site II and $X$. However, the amounts of copper due to anthropogenic origin ranged from $0-86.4 \%$. The possible sources of copper in these sites are engine wear and cassava wastes. With respect to contamination index, the soils can be ranked as slightly contaminated to very severe contamination (Table 7). The levels of copper observed in this study were higher than concentration of copper reported for soil of waste dump sites (Osakwe and Egharevba, 2008), mining sites (Gungshik and Mohammed, 2007), and foam manufacturing industry (Oviasogie and Omoruyi, 2007). Similar levels of copper have been observed in soils of oil field in the Niger Delta (Iwegbue et al., 2006a). However, higher levels of copper have been recorded in some contaminated sites (Iwegbue et al., 2006b; Kashem et al., 2007). 


\section{Zinc}

Zinc is ranked as third most abundant metal in this study. The concentrations of $\mathrm{Zn}$ in these soils spanned from 21.9 to $97.3 \mathrm{mg} \mathrm{kg}^{-1}$. The solubility of $\mathrm{Cu}$ and $\mathrm{Zn}$ is governed by the $\mathrm{pH}$ and redox conditions. In the $\mathrm{pH}$ range of 5.4-6.5, $\mathrm{Cu}$ and $\mathrm{Zn}$ are distinctly more soluble under oxidizing conditions than reducing conditions (Bhattacharya et al., 2002). The amounts of zinc that are of anthropogenic origin in these sites ranged from 19.9-82.0\% (Table 5). Majority of the sites have anthropogenic zinc fraction greater than $50 \%$. The major sources of zinc in these sites are probably the attrition of motor vehicle tyre rubber which is used as convoy belts in the mill and the lubricating oils which zinc is found as part of many additives as zinc dithiophosphates (Jaradat and Momani, 1999). The levels of zinc in these soils fits into the slightly contamination to severe contamination range. The levels of zinc found in the present study were lower than concentration of zinc reported for some contaminated sites in Nigeria (Bamgbose., 1999; Umoren and Onianwa, 2005; Iwegbue et al., 2006b) and other parts of the world (Abollino et al., 2002; Bhattacharya et al., 2002; Kashem et al., 2007). However, similar levels of zinc have been observed in soils around oil fields in Nigeria (Iwegbue et al., 2006a).

\section{Cadmium}

The concentration of cadmium in the examined site ranged between 0.01 and $1.60 \mathrm{mg} \mathrm{kg}^{-1}$. Sites III, IV, $\mathrm{VI}$ and had cadmium concentrations above the Department of Petroleum Resources target maximum allowed value of cadmium in soils. Like zinc, cadmium is found in lubricating oil as part of many additives. It was reported that cadmium level in car tyres is in the range of 20 to $90 \mu \mathrm{g} / \mathrm{g}$ as $\mathrm{Cd}$ contamination in the process of vulcanization (Jaradat and Momani, 1999). The levels of Cd could be due to lubricating oils and/or old tyres that are frequently used as convoy belt in machine and other associated wastes. The levels of cadmium observed in this study were similar to levels previously reported for soils of some contaminated sites in Nigeria (Aina and Sridhar, 2004; Iwegbue et al., 2006a; Nwajei et al., 2007; Iwegbue et al., 2009a). Much higher levels of cadmium in soil have been reported for some sites in Nigeria (Bamgbose et al., 2000; Iwegbue et al., 2006a; Oviasogie and Omoruyi, 2007). The fraction of $\mathrm{Cd}$ that is of anthropogenic origin is highest among the study metals. The contamination /pollution index of $\mathrm{Cd}$ ranged from 0.01 to 2.00 (Table 7). Hence, the soils could be ranked as very slightly contaminated to slightly polluted with cadmium.

\section{Lead}

Low levels of lead were generally observed in all sites. Similar low levels of lead have been observed in some sites in Nigeria (Oviasogie and Omoruyi, 2007; Gungshik and Mohammed, 2008; Gungshik et al., 2008). However, the levels of $\mathrm{Pb}$ reported herein are relatively low as compared to levels reported for some contaminated sites (Bamgbose et al., 2000; Onianwa and Umoren, 2005; Iwegbue et al., $2006 \mathrm{a}$, b; Inuwa et al., 2007; Nwajei and Iwegbue, 2007; Nwajei et al., 2007; Oviasogie and Ofomaja, 2007; Iwegbue et al., 2009a,b).

\section{CONCLUSION}

The levels of metals found in the present study were generally below the Department of Petroleum of Petroleum Resources target values for metals in soils. However, in some sites, Cd levels greater than the DPR target values. In spite of the fact that the levels of metals observed in present study were below target values were detected, significant fractions of these metals are due to anthropogenic input except for chromium and lead. Hence, soils around cassava processing mill should be of concern in order to prevent both surface and groundwater from excessive metal contamination.

\section{Acknowledgement}

The authors are grateful to Miss Gloria .K. Okparihi for her assistance during sampling and Mail in Oilfield laboratories, Warri, Nigeria for atomic absorption analysis. 
Table 4: Concentrations of heavy metals ( $\mathrm{mg} \mathrm{kg}^{-1} \mathrm{dry}$ weight) in soils in the vicinity of the cassava processing mill*.

\begin{tabular}{cccccccccc}
\hline Site & Depth $(\mathbf{c m})$ & $\mathrm{Mn}$ & $\mathrm{Ni}$ & $\mathrm{Fe}$ & $\mathrm{Cr}$ & $\mathrm{Cu}$ & $\mathrm{Zn}$ & $\mathrm{Cd}$ & $\mathrm{Pb}$ \\
\hline I & $0-15$ & 199.7 & 8.1 & 2681.0 & 0.78 & 9.3 & 89.2 & 0.48 & $<0.01$ \\
& $15-30$ & 149.2 & 4.1 & 2693.8 & 0.33 & 9.2 & 84.7 & 0.13 & $<0.01$ \\
II & $0-15$ & 355.3 & 9.9 & 2640.5 & 0.43 & 29.5 & 97.3 & 0.53 & $<0.01$ \\
& $15-30$ & 247.2 & 6.2 & 2641.1 & 0.10 & 7.5 & 75.3 & 0.05 & $<0.01$ \\
III & $0-15$ & 97.5 & 9.7 & 2839.4 & 0.78 & 9.3 & 89.2 & 0.90 & $<0.01$ \\
& $15-30$ & 84.7 & 8.1 & 2681.2 & 0.08 & 8.4 & 65.6 & 0.01 & $<0.01$ \\
IV & $0-15$ & 3.5 & 5.8 & 2694.7 & 0.28 & 9.6 & 26.9 & 1.60 & $<0.01$ \\
& $15-30$ & 0.1 & 5.5 & 2215.7 & 0.01 & 5.9 & 21.9 & 0.01 & $<0.01$ \\
V & $0-15$ & 17.8 & 5.8 & 2275.8 & 3.70 & 7.9 & 37.5 & 0.55 & $<0.01$ \\
& $15-30$ & 0.1 & 4.7 & 1746.4 & 0.24 & 5.8 & 29.5 & 0.48 & $<0.01$ \\
VI & $0-15$ & 238.4 & 11.3 & 2834.6 & 0.01 & 9.1 & 37.2 & 1.20 & $<0.01$ \\
& $15-30$ & 88.3 & 9.5 & 2696.9 & 0.01 & 6.2 & 25.7 & 0.01 & $<0.01$ \\
VII & $0-15$ & 64.5 & 9.5 & 2781.3 & 0.13 & 7.1 & 59.5 & 0.33 & $<0.01$ \\
& $15-30$ & 55.3 & 8.4 & 1786.2 & 0.13 & 3.7 & 44.9 & 0.01 & $<0.01$ \\
VIII & $0-15$ & 38.0 & 7.0 & 2153.9 & 0.01 & 8.4 & 54.5 & 0.68 & $<0.01$ \\
& $15-30$ & 25.4 & 4.2 & 2055.9 & 0.13 & 5.8 & 48.2 & 0.01 & $<0.01$ \\
IX & $0-15$ & 41.7 & 11.3 & 2616.9 & 0.01 & 6.2 & 37.2 & 1.20 & $<0.01$ \\
& $15-30$ & 54.7 & 7.0 & 2112.9 & 0.33 & 7.8 & 41.9 & 0.58 & $<0.01$ \\
X & $0-15$ & 383.2 & 9.9 & 2641.7 & 0.82 & 29.5 & 87.9 & 0.83 & $<0.01$ \\
& $15-30$ & 211.7 & 4.8 & 2083.6 & 0.24 & 16.5 & 53.4 & 0.01 & $<0.01$ \\
Control & $0-15$ & 36.1 & 2.5 & 1490.4 & 0.88 & 4.0 & 17.5 & 0.01 & $<0.01$ \\
\hline
\end{tabular}

*Mean of three subsamples assayed for each soil. The relative SDs for the three replicates are $<15 \%$ Manganese

Table 5: Anthropogenic input for heavy metals in soils in the vicinity of cassava processing mill

\begin{tabular}{cccccccccc}
\hline Site & Depth $(\mathbf{c m})$ & $\mathbf{M n}$ & $\mathbf{N i}$ & $\mathbf{F e}$ & $\mathbf{C r}$ & $\mathbf{C u}$ & $\mathbf{Z n}$ & $\mathbf{C d}$ & $\mathbf{P b}$ \\
\hline I & $0-15$ & 82.0 & 68.7 & 44.4 & 0.0 & 56.8 & 80.4 & 97.9 & 0.0 \\
& $15-30$ & 75.8 & 36.8 & 44.7 & 0.0 & 56.4 & 79.3 & 92.3 & 0.0 \\
II & $0-15$ & 89.9 & 74.4 & 43.6 & 0.0 & 86.4 & 82.0 & 98.1 & 0.0 \\
& $15-30$ & 85.4 & 59.2 & 43.6 & 0.0 & 46.3 & 76.7 & 80.0 & 0.0 \\
III & $0-15$ & 63.0 & 73.8 & 47.5 & 0.0 & 56.8 & 80.4 & 98.9 & 0.0 \\
& $15-30$ & 57.5 & 68.7 & 44.4 & 0.0 & 52.4 & 73.3 & 0.0 & 0.0 \\
IV & $0-15$ & 0.0 & 56.5 & 44.7 & 0.0 & 58.3 & 34.8 & 99.4 & 0.0 \\
& $15-30$ & 0.0 & 54.0 & 32.7 & 0.0 & 32.0 & 19.9 & 0.0 & 0.0 \\
V & $0-15$ & 0.0 & 56.6 & 34.5 & 76.2 & 49.2 & 53.2 & 98.2 & 0.0 \\
& $15-30$ & 0.0 & 46.6 & 14.7 & 0.0 & 31.5 & 40.5 & 97.9 & 0.0 \\
VI & $0-15$ & 84.9 & 77.6 & 47.4 & 0.0 & 56.2 & 52.9 & 99.2 & 0.0 \\
& $15-30$ & 59.2 & 73.3 & 44.7 & 0.0 & 35.0 & 31.7 & 0.0 & 0.0 \\
VII & $0-15$ & 44.1 & 73.2 & 46.4 & 0.0 & 43.9 & 70.5 & 97.0 & 0.0 \\
& $15-30$ & 34.8 & 69.9 & 16.6 & 0.0 & -8.11 & 61.0 & 0.0 & 0.0 \\
VIII & $0-15$ & 5.1 & 63.8 & 30.8 & 0.0 & 52.4 & 67.8 & 98.5 & 0.0 \\
& $15-30$ & 0.0 & 40.2 & 27.5 & 0.0 & 31.3 & 63.6 & 0.0 & 0.0 \\
IX & $0-15$ & 13.5 & 77.6 & 43.1 & 0.0 & 35.0 & 52.9 & 99.2 & 0.0 \\
& $15-30$ & 34.0 & 63.6 & 29.5 & 0.0 & 48.91 & 58.2 & 98.3 & 0.0 \\
X & $0-15$ & 90.6 & 74.4 & 43.6 & 0.0 & 86.4 & 80.1 & 98.8 & 0.0 \\
& $15-30$ & 83.0 & 47.3 & 28.5 & 0.0 & 75.9 & 67.2 & 0.0 & 0.0 \\
\hline
\end{tabular}


Iwegbue et al.: Assessment of Heavy Metal Contamination in Soils around Cassava Processing Mills in Sub-Urban...

Table 6: Enrichment factor for heavy metals in soils in the vicinity of cassava processing mill

\begin{tabular}{cccccccccc}
\hline Site & Depth (cm) & Mn & Ni & Fe & Cr & Cu & Zn & Cd & Pb \\
\hline I & $0-15$ & 3.10 & 3.19 & 1.80 & 0.89 & 2.31 & 5.09 & 48 & 1 \\
& $15-30$ & 3.89 & 1.58 & 1.81 & 0.38 & 2.30 & 4.84 & 13 & 1 \\
II & $0-15$ & 9.86 & 3.91 & 1.77 & 0.49 & 7.38 & 5.55 & 53 & 1 \\
& $15-30$ & 6.86 & 2.45 & 1.77 & 0.11 & 1.86 & 4.30 & 5 & 1 \\
III & $0-15$ & 2.70 & 3.81 & 1.91 & 0.89 & 2.31 & 5.09 & 90 & 1 \\
& $15-30$ & 2.35 & 3.19 & 1.80 & 0.09 & 2.10 & 3.74 & 1 & 1 \\
IV & $0-15$ & 0.10 & 2.30 & 1.81 & 0.32 & 2.40 & 1.53 & 160 & 1 \\
& $15-30$ & 0.00 & 2.17 & 1.49 & 0.01 & 1.47 & 1.25 & 1 & 1 \\
V & $0-15$ & 0.49 & 2.30 & 1.53 & 4.2 & 1.90 & 2.14 & 55 & 1 \\
& $15-30$ & 0.00 & 1.87 & 1.17 & 0.27 & 1.46 & 1.68 & 48 & 1 \\
VI & $0-15$ & 6.61 & 4.47 & 1.90 & 0.01 & 2.28 & 2.12 & 120 & 1 \\
& $15-30$ & 2.45 & 3.75 & 1.81 & 0.01 & 1.54 & 1.46 & 1 & 1 \\
VII & $0-15$ & 1.79 & 3.74 & 1.87 & 0.15 & 1.78 & 3.39 & 33 & 1 \\
& $15-30$ & 1.53 & 3.32 & 1.20 & 0.15 & 0.93 & 2.56 & 1 & 1 \\
VIII & $0-15$ & 1.05 & 2.76 & 1.45 & 0.01 & 2.10 & 3.11 & 68 & 1 \\
& $15-30$ & 0.70 & 1.67 & 1.38 & 0.15 & 1.46 & 2.75 & 1 & 1 \\
IX & $0-15$ & 1.16 & 4.47 & 1.81 & 0.01 & 1.54 & 2.12 & 120 & 1 \\
& $15-30$ & 1.52 & 2.75 & 1.42 & 0.38 & 1.96 & 2.39 & 58 & 1 \\
X & $0-15$ & 10.63 & 3.91 & 1.77 & 0.93 & 7.38 & 5.01 & 83 & 1 \\
& $15-30$ & 5.87 & 1.90 & 1.40 & 0.27 & 4.11 & 3.04 & 1 & 1 \\
\hline
\end{tabular}

Table 7: Contamination/pollution index for heavy metals in soils the vicinity of cassava processing mill

\begin{tabular}{ccccccccccc}
\hline Site & Depth $(\mathbf{c m})$ & $\mathrm{Mn}$ & $\mathrm{Ni}$ & $\mathrm{Fe}$ & $\mathrm{Cr}$ & $\mathrm{Cu}$ & $\mathrm{Zn}$ & $\mathrm{Cd}$ & $\mathrm{Pb}$ & $\mathrm{MPI}$ \\
\hline I & $0-15$ & 0.23 & 0.23 & 0.06 & 0.00 & 0.20 & 0.64 & 0.60 & 0.00 & - \\
& $15-30$ & 0.18 & 0.11 & 0.06 & 0.00 & 0.20 & 0.61 & 0.16 & 0.00 & - \\
II & $0-15$ & 0.42 & 0.28 & 0.06 & 0.00 & 0.80 & 0.70 & 0.66 & 0.00 & - \\
& $15-30$ & 0.29 & 0.18 & 0.06 & 0.00 & 0.20 & 0.54 & 0.06 & 0.00 & - \\
III & $0-15$ & 0.11 & 0.28 & 0.06 & 0.00 & 0.20 & 0.64 & 1.12 & 0.00 & 1.12 \\
& $15-30$ & 0.10 & 0.24 & 0.06 & 0.00 & 0.20 & 0.47 & 0.01 & 0.00 & - \\
IV & $0-15$ & 0.00 & 0.17 & 0.06 & 0.00 & 0.20 & 0.19 & 2.00 & 0.00 & 2.00 \\
& $15-30$ & 0.00 & 0.16 & 0.05 & 0.00 & 0.16 & 0.16 & 0.00 & 0.00 & - \\
V & $0-15$ & 0.02 & 0.17 & 0.05 & 0.03 & 0.20 & 0.27 & 0.69 & 0.00 & - \\
& $15-30$ & 0.00 & 0.14 & 0.04 & 0.00 & 0.16 & 0.21 & 0.06 & 0.00 & - \\
VI & $0-15$ & 0.28 & 0.33 & 0.06 & 0.00 & 0.25 & 0.27 & 1.50 & 0.00 & 1.50 \\
& $15-30$ & 0.10 & 0.27 & 0.06 & 0.00 & 0.17 & 0.18 & 0.01 & 0.00 & - \\
VII & $0-15$ & 0.08 & 0.27 & 0.06 & 0.00 & 0.29 & 0.42 & 0.41 & 0.00 & - \\
& $15-30$ & 0.07 & 0.24 & 0.04 & 0.00 & 0.10 & 0.32 & 0.01 & 0.00 & - \\
VIII & $0-15$ & 0.04 & 0.20 & 0.05 & 0.00 & 0.23 & 0.39 & 0.85 & 0.00 & - \\
& $15-30$ & 0.03 & 0.12 & 0.04 & 0.00 & 0.16 & 0.34 & 0.01 & 0.00 & - \\
IX & $0-15$ & 0.05 & 0.33 & 0.06 & 0.00 & 0.17 & 0.27 & 1.50 & 0.00 & 1.50 \\
& $15-30$ & 0.06 & 0.20 & 0.04 & 0.00 & 0.20 & 0.30 & 0.73 & 0.00 & - \\
X & $0-15$ & 0.45 & 0.28 & 0.06 & 0.00 & 0.81 & 0.63 & 1.04 & 0.00 & 1.04 \\
& $15-30$ & 0.25 & 0.14 & 0.04 & 0.00 & 0.45 & 0.38 & 0.01 & 0.00 & - \\
\hline
\end{tabular}

MPI= Multiple Pollution Index 


\section{REFERENCES}

Abollino, O.M., Malandrino, M., Menstasti, E. and Petrella, F. (2002). Heavy metals in Agricultural soils from Piedmount, Italy: distribution, speciation and chemometric data treatment. Chemosphere, 49: $545-557$.

Adriano, D.C. (2001). Trace metals in terrestrial environment. Biochemistry, bioavailability and risk of metals. Springer-Verlag, New York. Pp879

Aina, G.R.E. and Sridhar, M.K.C. (2004). Soil quality near a fertiliser industry at Port Harcourt, Nigeria. AJEAM - RAGEE 8:19-26

Asaah. V.A., Abimbola, A.F. and Such, C.E. (2005). Heavy metal concentrations and distribution in surface soils of the Bassa industrial zone 1, Douala, Cameroon. Arabian Journal for Science and Engineering, 31(2A): 147-158.

Bamgbose O., Odukoya, O. and Arowolo, T.O.A. (2000). Earthworm as bioindicator of heavy metal pollution in dumpsite of Abeokuta city, Nigeria. Revista de Biologia Tropical, 48(1): 229-234.

Bhattacharya, P., Mukherjee, A.B., Jack, G. and Nordquist, S. (2002). Metals contamination at a wood preservation site: characterisation and experimental studies on remediation. Science of the Total Environment, 290: 165-180.

DPR (Department of petroleum resources) (2002). Environmental guidelines and standards for the petroleum industry in Nigeria (revised edition). Department of Petroleum Resources, Ministry of Petroleum and Natural Resources, Abuja, Nigeria.

El-Hassan, T., Batarseh, M., Al-Omari, H., Ziadat, H., El-Alali, A., Al-Naser, F., Berdainer, B.W. and Jiries, A.(2006). The distribution of heavy metals in urban street dust of Karak city, Jordan. Soil and Sediment Contamination, 15: 357-365.

Gallego, J.L.R., Ordonez, A. and Loredo, J. (2002). Investigation of trace element sources from an industrialised area (Aviles, northern Spain) using multivariate statistical methods. Environmental International 27: 589-596

Gungshik, J,R. and Mohammed, J.D. (2007). Impact of mining on trace metal contents of soil. African Journal of Natural Sciences 10: 21-24

Gungshik, J.R., Lohdip, Y.N. and Bewarang, E.S. (2007). Speciation of trace metals in top soils in Jos industrial areas. African Journal of Natural Sciences, 10: 15-19.

Oguntimehin I and Ipimoroti K. (2008). Profile of heavy metals from automobile workshops in Akure, Nigeria. Journal of Environmental Science and Technology, 1(1): 19-26.

Inuwa, M., Abdulrahman, F.W., Birnin Yauri, U.A. and Ibrahim, S.A. (2007). Analytical assessment of some traces metals in soils around a major industrial area in Northwestern Nigeria. Trends in Applied Science Research, 2(26): 515-521.

Iwegbue, C.M..A. (2007). Distribution of heavy metals in sediments and surface water of crude oil impacted area in the Niger Delta, Nigeria. Pakistan Journal of Scientific and Industrial Research, 50(3): 178-183.

Iwegbue, C.M.A., Egobueze, F.E. and Opuene, K. (2006 a). Preliminary assessment of heavy metals in soils of an oil field in the Niger Delta, Nigeria. International Journal of Environmental Science and Technology, 3(2): 167-172.

Iwegbue, C.M.A., Isirimah, N.O., Igwe, C. and Williams, E.S. (2006 b). Characteristic level of heavy metals in soil profiles of automobile mechanic waste dumps in Nigeria. Environmentalist, 26: 131-137.

Iwegbue, C.M.A., Nwajei, G.E., Egauvoen, I.O and Ogala, J.E. (2009 a). Chemical fractions of some heavy metals in soil profiles in the vicinity of scrap dumps in Warri, Nigeria. Chemical Speciation and Bioavailability, 21(2): 99-110.

Iwegbue, C.M.A., Williams, E.S. and Isirimah, N.O. (2009b). Study of heavy metals distribution in soils impacted with crude oil in southern Nigeria. Soil and Sediment Contamination, 18:136-143.

Jaradat, Q.M. and Momami, K.A. (1999). Contamination of roadside soils, plants and air with heavy metals in Jordan: a comparative study. Turkish Journal of Chemistry, 23: 209-220.

Kashem, M.A., Singh, B.R., Kondo, T., Imame Huq, S.M. and Kawai, S. (2007). Comparison of extractability of $\mathrm{Cd}, \mathrm{Cu}, \mathrm{Pb}$ and $\mathrm{Zn}$ with sequential extraction in contaminated and non-contaminated soils. International Journal of Environmental Science and Technology, 4(2): 169-176.

Lacutusu, R. (2000). Appraising levels of soil contamination and pollution with heavy metals In Heinike H. J.,.Eckselman W., Thomasson A.J., Jones R.J.A, Montanarella L. and Buckeley B.(eds.). Land information systems for planning the sustainable use of land resources. European Soil Bureau Research Report No. 4. Office of Official Publication of the European Communities, Luxembourg, pp 393-402

Machender, G., Dhakate, R., Prasanna, L. and Govil, P.K. (2010). Assessment of heavy metals contamination in soils around Balanagor industrial area, Hyderabad, India. Environmental Earth Science, 63(5): 945-953.

Mapanda, F., Mangwayana, E.N., Nyamangara, J. and Giller, K.E.( 2005). The effect of long term irrigation using waste water on heavy metal 
content of soil under vegetables in Harare, Zimbabwe. Agriculture, Ecosystem and Environment, 107: 151-165.

Moon, J.W., Moon, H.S., Woon, N.C., Hahn, J.S., Won, J,S., Song, Y., Lin, X. and Zhao, Y. (2000). Evaluation of heavy metals contamination and implication of multiple sources from Hunchun basin, north eastern China. Environmental Geology, 39: 1039-1052.

Noma, S.S., Oroluleke, J.O., Yakubu, M., Yalewa, S.A. and Manga, S.B.(2008). Influence of land use in soil organic carbon and microbial biomass in Sokoto area, Nigeria. Nigerian Journal of Basic and Applied Science, 16(1): 90-97

Nwajei, G.E. and Iwegbue, C.M.A. (2007). Trace metal concentrations in the vicinity of Uwelu motor spare parts market, Benin City, Nigeria. Journal of chemical society of Nigeria 32 (2): 283-286

Nwajei, G.E., Iwegbue, C.M.A and Okafor, M.I.(2007). Heavy metals in surface soils under waste dumps from Onitsha. Nigerian Journal of Biological Sciences 7(2): 405-408

Onianwa, P.C. (2001). Roadside topsoil concentrations of lead and other heavy metals in Ibadan, Nigeria. Soil and Sediment Contamination, 10: 577-591

Onianwa, P.C. and Fakayode, S.O. (2000). Lead contamination of topsoil and vegetation in the vicinity of a battery factory in Ibadan. Environmental Geochemistry and Health, 22: 211218

Osakwe, S.A and Egharevba, F. (2008). Sequential fractionation of cadmium, copper, lead and chromium in soils around municipal solid waste dumps in Agbor, Nigeria. Journal of Chemical Society of Nigeria, 33(2): 139-147

Oviasogie, P.O and Ofomaja, A. (2007). Available $\mathrm{Mn}, \mathrm{Fe}, \mathrm{Pb}$ and physicochemical changes associated with soil receiving cassava mill effluent. Journal of Chemical Society of Nigeria, 32(1): 69-73

Oviasogie, P.O. and Omoruyi, E. (2007). Levels of heavy metals and physicochemical properties of soil in a foam manufacturing industry. Journal of Chemical Society of Nigeria, 32(1): 102-106.

Radojevic, M. and Bashkins, V.N. (1999). Practical environmental analysis. Royal Society of Chemistry, Cambridge, UK

Reeuwijk, L.P. (ed) (1995). Procedure for soil analysis. Technical paper $95^{\text {th }}$ ed, 1995. ISRIC, Wageningen, the Netherlands

Sheppard, D.S., Claridge, G.G.C. and Campbell, I.B.(2000). Metal contribution of soil at Scott urban-rural land use gradients. Applied Geochemistry, 15: 513-530.

Umoren, I.U. and Onianwa, P.C. (2005). Concentrations and distribution of some heavy metals in urban soils of Ibadan, Nigeria. Pakistan Journal of Science and Industrial Research, 48(6): 397-403

Wu, C. and Zhang, L. (2010). Heavy metal concentrations and their possible sources in paddy soils of a modern agricultural zone, south eastern China. Environmental Earth Science, 60: 45-56.

Skorda K. and Kelepertsis A. (2005). Soil contamination by toxic metals in the cultivated region of Agia, Thessaly, Greece: Identification of sources of contamination. Environmental Geology, 48: 615-624.

WHO (World Health Organization) (2004). Guidelines for drinking water quality, $3^{\text {rd }}$ edn..Retrieved from http://www.who.int/watersanitation health/dwg/guidelines/en.

USEPA (United State Environmental Protection Agency) (2003). Drinking water contaminants. National primary water regulations, EPA-816-F03-016. 